\title{
Natural polymer flow behaviour in porous media for enhanced oil recovery applications: a review
}

\author{
Augustine Agi ${ }^{1} \cdot$ Radzuan Junin $^{1} \cdot$ Jeffrey Gbonhinbor ${ }^{2,3} \cdot$ Mike Onyekonwu $^{3}$
}

Received: 11 June 2017 / Accepted: 14 January 2018 / Published online: 30 January 2018

(c) The Author(s) 2018. This article is an open access publication

\begin{abstract}
When a reservoir is flooded with polymer, the mobility ratio between the displaced fluid and the displacing fluid become favourable compared to the conventional water flooding. In the oil and gas industry, the synthetic polymer polyacrylamide in hydrolysed form and the biopolymer xanthan are being used for this purpose. However, the polyacrylamide is susceptible to high temperature and salinity. Also, its synthetic nature makes it harmful to the environment. The biopolymer xanthan has the problem of degradation and both are very expensive. With the shortfall in crude oil price and the high cost of exploitation and drilling new wells, there is need to look inward and think out of the box in formulating new improved polymers that can combat these problems. Natural polymers from agricultural and forest produce are abundant in nature, cheap and environmentally friendly. These agricultural and forest produce contain starch and cellulose which are known to have rigid and long polysaccharide chains that can withstand the harsh reservoir conditions. But the design of a polymer flood or a permeability-modified process involving polymer requires knowledge about the polymer flow mechanism and the rheological behaviour of the porous media. This paper, therefore, reviews the available natural polymers that can be used for enhanced oil recovery applications and the mechanism affecting their flow behaviour in porous media. The emphasis is on the physical aspect of the flow, the microscopic rheological behaviour of the natural polymers. The dominant mechanism of the flow process was adsorption, mechanical entrapment and hydrodynamic retention. It was observed that the polymer exhibited non-Newtonian, pseudoplastic and shear-thinning behaviours. The literature review on oil displacement test indicates that natural polymers can recover additional oil from an oil field. Environmental application issues associated with the application of natural polymers have opened new frontier for research and are also highlighted herein.
\end{abstract}

Keywords Polymer $\cdot$ Retention $\cdot$ Rheology $\cdot$ Porous media $\cdot$ Enhanced oil recovery

\section{Introduction}

Enhanced oil recovery (EOR) is a method of recovering hydrocarbon where the compressional energy of the reservoir is used to force oil to the producer wells, with a drop-in reservoir pressure. It is, therefore, a process that recovers

Radzuan Junin

r-razuan@utm.my

1 Department of Petroleum Engineering, Faculty of Chemical and Energy Engineering, Universiti Teknologi Malaysia, UTM Skudai, 81310 Johor Bahru, Malaysia

2 Department of Petroleum Engineering, Faculty of Chemical Engineering, Niger Delta University, Wilberforce Island Amassoma, Bayelsa State, Nigeria

3 Department of Petroleum and Gas Engineering, University of Port-Harcourt, Port-Harcourt, Nigeria oil that was not originally produced from the reservoir. Hydrocarbon recovery occurs through three stages; primary recovery, secondary recovery and tertiary recovery. Primary recovery occurs when the reservoir uses its natural energy to force the oil to the well bore, and it is usually referred to as the initial production stage. There are six driving mechanisms that produce this natural energy for oil recovery. They include gas cap drive, combination drive, rock and liquid expansion drive, water drive, gravity drainage drive and depletion drive. Rock properties, fluid properties, and geological heterogeneities influence primary recovery. Primary recovery can recover from zero to over $50 \%$ of the original oil in place (OOIP); this depends on the hydrocarbon type and the reservoir drive mechanism. For instance, the primary recovery from oil sands is zero, whereas the recovery from a water drive and light oil reservoir can reach up to $50 \%$ or 
more in an effective gravity driven reservoir (Farouq-Ali and Thomas 1996).

When the reservoir energy is depleted, secondary recovery which is aimed at providing additional energy to boost or maintain the production level through injection of fluid is applied. Secondary recovery uses injections to re-pressurise the reservoir and displace oil to the producing well. Which is done through the injection of water or gas, water flooding is therefore referred to as secondary recovery (Ahmed and McKinney 2005).

The tertiary recovery which is also known as EOR targets what is left. It also involves the injection of fluids or gas into the reservoir but aimed at reducing the forces such as viscous and interfacial forces holding the oil, to make it easy for production. The gases used in EOR process include nitrogen, hydrocarbon, carbon dioxide $\left(\mathrm{CO}_{2}\right)$, and flue. Polymers, surfactants, and hydrocarbon solvents are the liquid chemicals used. Polymer is used to improve the sweep efficiency by changing the mobility ratio; the surfactant lowers the interfacial tension between the oil and displacing fluid (Stosur 2003; Abbas et al. 2017).

Therefore, in classifying the recovery process, there is need for caution because many reservoir operations are not conducted in the specific order listed above. For instance, in the production operations of heavy oil, if the crude oil is too viscous, it might not be economical to flow under natural energy drives. The primary recovery will be neglected; waterflooding is also not useful. The thermal recovery might be the only way to recover a significant amount of oil. In this case, a supposed tertiary process becomes the first stage; this can also apply where the secondary process is skipped. Also, in many cases, the polymer flooding is applied as a secondary recovery in place of waterflooding, when the oil is viscous (Farouq-Ali and Thomas 1996). The summary of the hydrocarbon recovery stages, their estimated recovery efficiency, and techniques identified in each process is shown in Fig. 1.

Microbial enhance oil recovery is also an EOR method; it is the use of micro-organism to extract the remaining oil from the reservoirs. It can recover $50 \%$ of the residual oil (Lazar et al. 2007). The principle behind this method is that micro-organism together with source nutrient is injected into reservoirs where they produce $\mathrm{H}_{2}, \mathrm{CO}_{2}$ and surfactants that help to mobilise the oil. Micro-organisms that can be used for microbial EOR include protozoa, fungi, algae, and aerobic and anaerobic bacteria.

Many EOR methods have been devised to recover more oil from the reservoir. Starting with the injection of water to various types of gases and liquids, many studies have reported success, but the additional cost of injecting chemicals and gases in relation to the cost of oil often kept the study at laboratory stage. But the present state of modern industrial development is characterised by the consumption of enormous quantities of petroleum products. As the demand for petroleum products continue to rise due to increase in world population, petroleum production worldwide continues to decline (Wei and Sepehrnoori 2014). Since oil production grows at a rate greater than reserve addition, there is a need to boost the reserve, and this lies with sustaining production from existing fields. One of the
Fig. 1 Enhanced oil recovery/ improved oil recovery definition

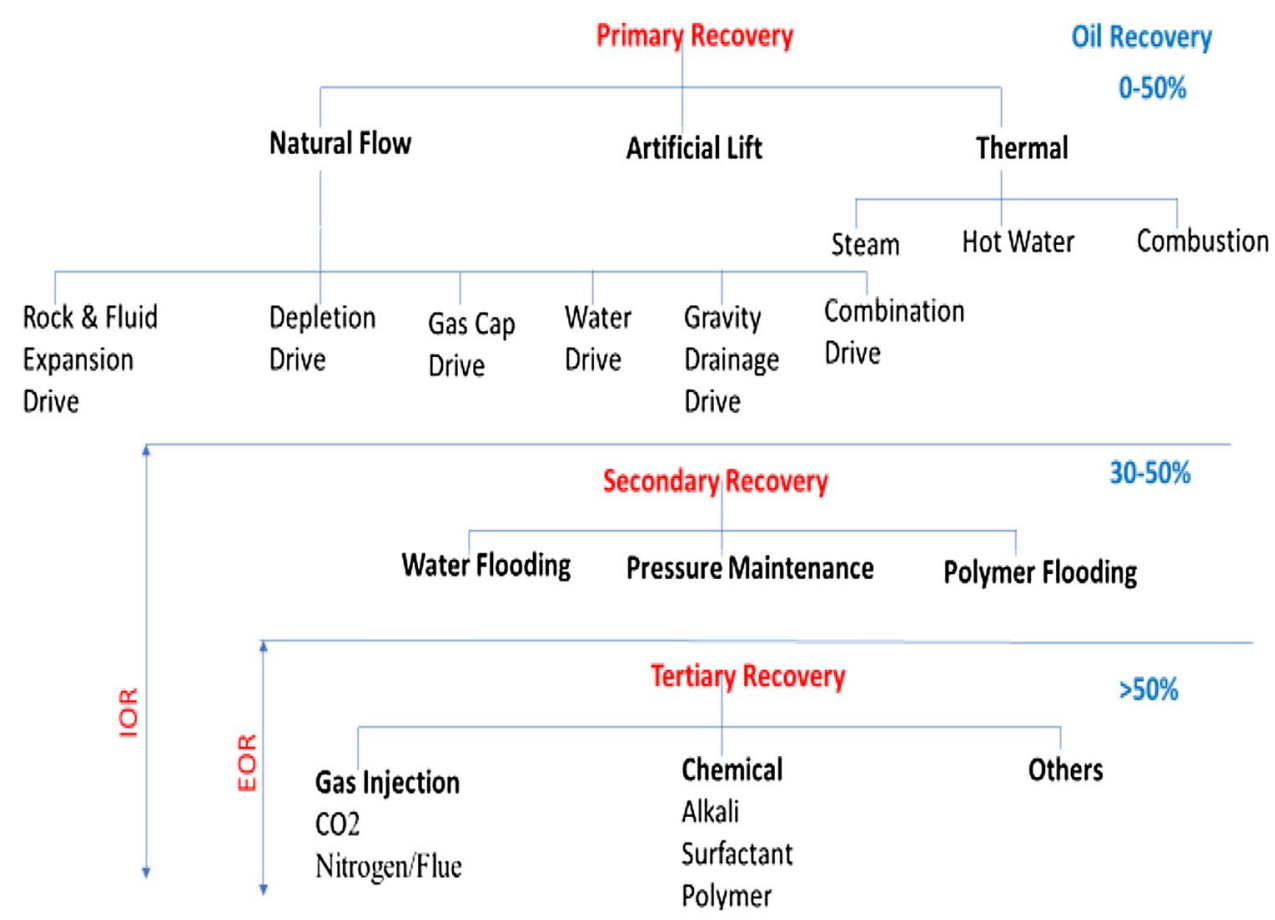


recommended ways of achieving this is by polymer flooding method. It is widely used since its inception in the 1960s, the main reason for its introduction is to remedy the problem pose by waterflooding such as heterogeneity and high mobility ratio $(\mathrm{M})$. Polymer flooding is aimed at reducing the mobility ratio by increasing the water viscosity and reducing the formation permeability. The beauty of using polymer to reduce mobility ratio is that they can increase the viscosity of the injected brine by factors of between 3 and 20 at low concentration of a few hundred parts-per-million (ppm) by weight (Sorbie 1991). All the early works on polymer were of the synthetic type, polyacrylamide (PAM), which is usually in hydrolysed form (HPAM). HPAM is widely used in the oil industry because it has made its name in other industry like paper making and flocculation application as such was commercially available. Biopolymer, xanthan, has been developed for field polymer flooding application. Xanthan, however, has found its application in few industries like food and confectionary before being used in oil recovery (Sorbie 1991).

Starches and cellulose are the most abundant natural polymers in the world. The advantages of selecting them as a starting raw material to produce polymers for EOR is because they are in abundance, readily available, environmentally friendly, and biodegradable. Also, easy to handle, their rigid structure and long polysaccharides chains make them suitable to withstand the harsh reservoir conditions. Research has shown that natural polymers can enhance oil recovery. The natural polymers that have been tested at laboratory scale to enhance recovery include; okra (Ade and Onyekonwu 2012; Ihebuzor and Onyenkonwu 2012; Ojo et al. 2013); cassava starch (Samuel and Onyekonwu 2012; Ikeagwu and Adetila 2015); Datarium microcarpum (Osuji and Onyenkonwu 2012); gum Arabic (Ihebuzor and Onyekonwu; Ade and Onyekonwu; Irvingia gabonensis (Ihebuzor and Onyenkonwu 2012; Ade and Onyekonwu 2012; Samuel and Onyekonwu 2012; Ajabuego and Onyekonwu 2012; Ojukwu et al. 2013; Ogolo et al. 2015; Ikeagwu and Adetila 2015; Brachystegia eurycoma (Ajabuego and Onyekonwu 2012; Ogolo et al. 2015); exudate gum (Ajabuego and Onyekonwu 2012); aqueous beans (Gbonhinbor and Onyekonwu 2015) and schizophyllan (Goa 2016). The basic properties of these natural polymers are shown in Table 1.

Polymer field applications saw a lot of success in the 1960s and 1970s, which led to better polymer formulation for oil recovery application. This brought insight to the flow of polymer in a porous medium; polymer flooding is, therefore, an improved oil recovery (IOR) method where field application precedes detail knowledge of the entire process. There are still a lot of issues in polymer flooding which are poorly understood; there is, therefore, much need for the development of new and modified polymers for IOR applications.
Most of the polymers used in the oil and gas industries are imported from other countries, as such it takes a lot of time and money before these polymers get to their destination of use, couple with fact that some need to be used within 6 month of purchase which is a major problem in the oil and gas company. The HPAM, which is currently in use in the industries, is susceptible to high temperature and salinity and its synthetic nature makes it harmful to the environment. The biopolymer xanthan has the problem of degradation, and both are very expensive. With the shortfall in crude oil price and the high cost of exploitation and drilling new wells (Agi et al. 2017), there is need for us to look inward and think out of the box in formulating new improved polymers that can combat the problems aforementioned. The objectives of this paper therefore to: (1) review locally formulated polymers that can be used for EOR activities; (2) determine the behaviour of these natural polymers in porous media, concentrating on their retention and rheology; (3) compile the experimental studies on the recent advances on natural polymer flooding process as it affects incremental oil recovery; (4) highlight the environmental issues associated with the manufacture and use of these natural polymers and outlines the preferred solutions; and (5) discuss the flow and interaction of contaminants with the porous media.

\section{Polymer flow behaviour}

The flow of polymer in solution is still very less understood, even with the level of research on the area. There have been many proposals, which indicate lack of consensus among researchers with respects to the mechanisms of polymer flow behaviour. The complex nature of the flow of polymer in porous media has led to lack of consensus among researchers; therefore, the emphasis here will be on the physical aspect of the flow; the microscopic rheological behaviour and the retention of the polymer will also be discussed.

Flow-induced crystallization, precipitation of gel-like particles, solid fibre formation, flow-induced laziness are some of the effects of the flow of polymer in solution (Larson 1992). Therefore, the rheological behaviour and retention of polymer solutions are important in explaining important observation when these solutions are subjected to flow.

The major reason for adding polymer to displacing fluids is to make the fluid viscous, but there may be some reaction between the polymer and the reservoir which cause some of the polymer to be retained by the reservoir. This will form a barrier for any other polymer to be injected into the reservoir; the fluid forming a barrier will have a lower viscosity than any other injected polymer which will make the polymer to be less effective. Also, this may lead to reduction in permeability of the rock, which will in turn affect recovery. With view of the highlighted facts, the success of a polymer flood depends on how you can minimise the amount of 
Table 1 Basic properties of natural polymers

\begin{tabular}{|c|c|c|c|c|c|c|}
\hline Natural polymers & Moisture content (\%) & Bulk density & Porosity (\%) & Viscosity & $\mathrm{pH}$ & References \\
\hline Okra & $11.42-14.83$ & $450.42 \mathrm{~kg} / \mathrm{m}^{3}$ & 39.43 & $62.32-228.78 \mathrm{cP}$ & 6.59 & $\begin{array}{l}\text { Owolarafe and Shotonde } \\
\text { (2004); Zaharuddin et al. } \\
\text { (2014) }\end{array}$ \\
\hline Cassava starch & $11.8-41$ & $0.64-0.68 \mathrm{~g} / \mathrm{cm}^{3}$ & $10-60$ & $2913 \mathrm{cP}$ & 5.82 & $\begin{array}{l}\text { Karathanos and Saravacos } \\
\text { (1993); Araujo-Farro et al. } \\
\text { (2005); Gbadamosi and } \\
\text { Oladeji (2013); Belibi et al. } \\
\text { (2014) }\end{array}$ \\
\hline Gum Arabic & $9.76-10.77$ & $0.5 \mathrm{~g} / \mathrm{mL}$ & 52.65 & $1560-2076 \mathrm{cP}$ & 4.94 & $\begin{array}{l}\text { Chen and D'Auria (2010); } \\
\text { Daoub et al. (2016); Bashir } \\
\text { and Haripriya (2016). }\end{array}$ \\
\hline Exudate gum & $2.04-12.23$ & $0.600 \mathrm{~g} / \mathrm{mL}$ & 42.06 & $1.73-1.95 \mathrm{dL} / \mathrm{g}$ & 5.7 & $\begin{array}{l}\text { Bashir and Haripriya (2016); } \\
\text { Mahfoudhi et al. (2012) }\end{array}$ \\
\hline Detarium microcarpum & $3.5-28.5$ & $0.44-0.86 \mathrm{~g} / \mathrm{cm}^{3}$ & $30-75.51$ & 37.5-65.5 mPa.s & 7.68 & $\begin{array}{l}\text { Onweluzo et al. (1999); } \\
\text { Akpata and Miachi (2001); } \\
\text { Adedeji et al. (2012); Okolo } \\
\text { et al. (2014); Aviara et al. } \\
\text { (2015); Owuamanam et al. } \\
\text { (2016) }\end{array}$ \\
\hline Irvingia gabonensis & $6.2-43.14$ & $0.368 \mathrm{~g} / \mathrm{cm}^{3}$ & $61.62-66.1$ & $3.85-5.19 \mathrm{cP}$ & 5.84 & $\begin{array}{l}\text { Onimawo et al. (2003); Ogaji } \\
\text { et al. (2012); Nwigbo et al. } \\
\text { (2013); Bamidele et al. } \\
\text { (2015) }\end{array}$ \\
\hline Brachystegia eurycoma & $2.79-27.13$ & $613.6-745.4 \mathrm{~kg} / \mathrm{m}^{2}$ & $11.23-80.9$ & $490-914 \mathrm{cP}$ & 5.38 & $\begin{array}{l}\text { Ndukwu (2009); Ikegwu et al. } \\
\text { (2010); Uhumwangho and } \\
\text { Ileje (2014); Aviara et al. } \\
\text { (2015) }\end{array}$ \\
\hline Beans & $10.5-11.9$ & $0.708 \mathrm{~g} / \mathrm{cm}^{3}$ & 44.1 & $591-1030.3 \mathrm{cP}$ & $6.31-6.46$ & $\begin{array}{l}\text { Abuajah and Alonge (2013); } \\
\text { Wani et al. (2013); Marquezi } \\
\text { et al. (2017) }\end{array}$ \\
\hline Schizophyllan & 6.3 & $0.75 \mathrm{~g} / \mathrm{mL}$ & & $25-45 \mathrm{cP}$ & $4.9-5.1$ & $\begin{array}{l}\text { Hatscher (2016); Joshi et al. } \\
\text { (2016) }\end{array}$ \\
\hline
\end{tabular}

polymer retained (Sorbie 1991). There are three major mechanism which act on polymer when it flows through porous media; polymer adsorption, mechanical entrapment and hydrodynamic retention (Willhite and Dominguez 1977).

\section{Natural polymer adsorption}

Polymer adsorption can simply be defined as the interaction between the solid surface (soft rock) and the polymer molecules. It allows the polymer to be physical adsorbed to the surface of the solid, hydrogen bond and van der Waal's forces acting on the molecules and solid surface. The polymer usually adsorbs on the surface of the solid, and if the surface area of the solid is large, the higher the level of adsorption (Sorbie 1991; Sheng 2011).

\section{Mechanical entrapment}

Mechanical entrapment and hydrodynamic retention are similar, and both only occur in porous media. They are not involved in free powder/bulk solution experiments. Mechanical entrapment occurs when large molecules of polymer are trapped in narrow flow channels (Willhite and Dominguez 1977). Polymer mechanical entrapment can be summarised based on the deep-bed filtration phenomena by Herzig et al. (1990);

(a) The concentration at the end of the core would fail to reach the desired input concentration, or will do so when a lot of polymer pore volume passes through which could lead to blockage and allowing polymer to flow through other channels that are bigger.

(b) Also, the distribution of the polymer will not be uniform allowing large polymers at the core close to the inlet and decreasing in that order. 
(c) Finally, there are several entrapment areas, the media will be completely blocked, and the permeability will fall to zero.

\section{Hydrodynamic retention of polymer}

This is the least understood retention mechanism and not well defined. The idea of polymer retention was based on laboratory observation of several authors (Desremaux et al. 1971; Maerker 1973; Chauveteau and Kohler 1974; Dominguez and Willhite 1977) that, after attaining a steady state in a polymer retention experiment in a core, the level of retention changed when the fluid flow rate was adjusted to a new value. Hydrodynamic retention is rate depended; however, it does not contribute much to the overall level of polymer retention in porous media, and not very important in field polymer flood process. It is very useful in laboratory floods to interpret correctly polymer adsorption and retention mechanism. It mainly occurs in low permeability material with small pore size and increase at residual oil as compared to a fully water-saturated situation (Szabo 1975). Furthermore, it is also used to study the relationship between the polymer and porous media. Retention through mechanical entrapment should be screened and avoided; it is usually small and can be neglected in most practical cases. Three mechanism of polymer retention can be avoided by pre-filtering or pre-shearing by reducing the large polymer molecules or by applying the polymer in a high permeability formation. However, because of the difficulty in differentiating between these mechanisms in flood test, most authors prefer to use a single term of retention or adsorption to describe the loss of polymer in porous media.

Ikeagwu and Adetila (2015) in their work on Cassava Starch and Irvingia gabonensis reported that steady viscosity increase resulted in oil recovery up to $2.5 \mathrm{cp}$ where the core stopped responding to flooding and no more oil or water was recovered; this could be as a result of the polymer retention in the media, which resulted to plugging. This can also be noticed in the work of Ajabuego and Onyekonwu (2012) who also notice that, during the flooding with Irvingia gabonensis, that there was pressure build-up and low flow rate, this could be because of polymer retention in the porous media.

Ojukwu et al. (2013) also reported that as the viscosity of a polymer increases, it can also lead to poor recovery because most of the polymer will begin to be retained by the formation, thereby forming a bank, preventing further intake of polymer and subsequently reducing recovery. Osuji and Onyenkonwu (2012) also experienced a similar problem in their work on Detarium microcarpum. Detarium microcarpum absorbed water and solidify thereby blocking pore spaces.
Alcohol can also be added to the polymer as a pre-shearing mechanism to reduce the molecular structure of the polymer to prevent retention. The experimental work of Ikeagwu et al. (2013), they used alcohol from palm wine to reduce the molecular structure of cassava starch, and it yielded a good result. Qiao and Zhu (2009) also suggested the injection of a fluid to improve the injection profile and oil recovery in the stage of succeeding water recovery. Since the validity period of the method is long; it can also use the polymer solution underground effectively to resolve the problem of fluid loss.

\section{Natural polymer rheology in porous media}

Viscosity is also one of the important parameters when discussing polymer rheology, the bulk viscosity is measured with a viscometer, while the in situ viscosity is measured in the porous media. It is not directly measured, but instead it is calculated according to the Darcy equation using core flood data, the calculated viscosity is called the apparent viscosity (Sorbie 1991).

Experimentally, the use of sand and beads pack have provided the most widely used models of porous media for carrying out in situ rheological measurements. In this method, the porous media can be scaled, according to the particle size. It is widely accepted that displacement test should be carried out on consolidated porous media to depict the reservoir condition. This could be very useful when carrying out polymer adsorption measurement; however, some useful measurement like generic feature of the in situ rheology of the polymer can be done in unconsolidated porous media. When you require specific field design data, the consolidated or actual reservoir cores should be used (Sorbie 1991).

Rheology, therefore, can be defined as the study of flow and deformation of matter. As such, the study of rheology is important when talking about flow in porous media; it helps us to understand the behaviour of these fluids. Fluid in porous media can be classified as Newtonian and non-Newtonian. For Newtonian fluid, the viscosity is expressed by the relationship between the stress and shear rate. In Newtonian fluid, the viscosity remains constant, no matter the amount of shear applied; therefore, the relationship between the viscosity and shear stress is linear. That is, a graph of viscosity versus shear stress is a straight line: examples are water, alcohol, gasoline, mineral oil. The fluid experiences a direct proportionality between the stress and strain and the flow is laminar (Sochi 2010).

On the other hand, the viscosity of non-Newtonian fluid thus not have a constant viscosity at all shear rate, as such effective or apparent viscosity is used to describe the viscosity of fluid at a shear rate. Therefore, non-Newtonian fluid is fluid where the proportionality between the stress and strain is not linear. Non-Newtonian fluids can be classified into

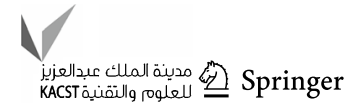


four major group: the dilatant where the viscosity of the fluid increases when shear is applied, for example, quicksand, corn flour, and water; the pseudoplastic, in this case, the more shear is applied, the fluid become less viscous, for example, ketchup, polymer, which is our area of interest; rheopectic, this is similar to dilatant but the difference is when shear is applied, the viscosity increases with time, that is, it is time-dependent example: we have cream, gypsum paste; thixotropic here where shear is applied, the viscosity decreases with time, which makes it also time-dependent examples: paint, cosmetic, asphalt, and glue. We can, therefore, conclude that non-Newtonian fluid is either timedependent or non-time-dependent.

Liu et al. (2014) studied the rheology of cassava starch to produce adhesives and reported that the apparent viscosity of cassava starch decreases slowly with the increase in the speed of the rotor; it also exhibited shear-thinning behaviour and the fluid was pseudoplastic. The work of Che et al. (2008) on dilute aqueous solution of cassava starch also exhibited shear-thinning behaviour, the cassava starch changed from Newtonian to non-Newtonian when the concentration was increased above $0.4 \%$; the power-law model, Bingham model and Herschel-Bulkley model are suitable for representing the flow behaviour of the fluid. Mechanical activation decreases the apparent viscosity of cassava starch; this apparent decrease in viscosity with increase in shear rate demonstrates the shear-thinning nature exists (Huang et al. 2006). Figure 2 is a graph of stress versus strain.

Alamri et al. (2012) in their work on okra using the Brookfield rheometer found out that the profile demonstrated an increase in shear stress at higher shear rate confirming pseudoplasticity of the fluid and conform with the power-law model. This is also similar to the findings of Georgiadis et al. (2010), which also reported that okra demonstrated a shear-thinning behaviour at high concentration. Sengkhamparn et al. (2009) in their work on

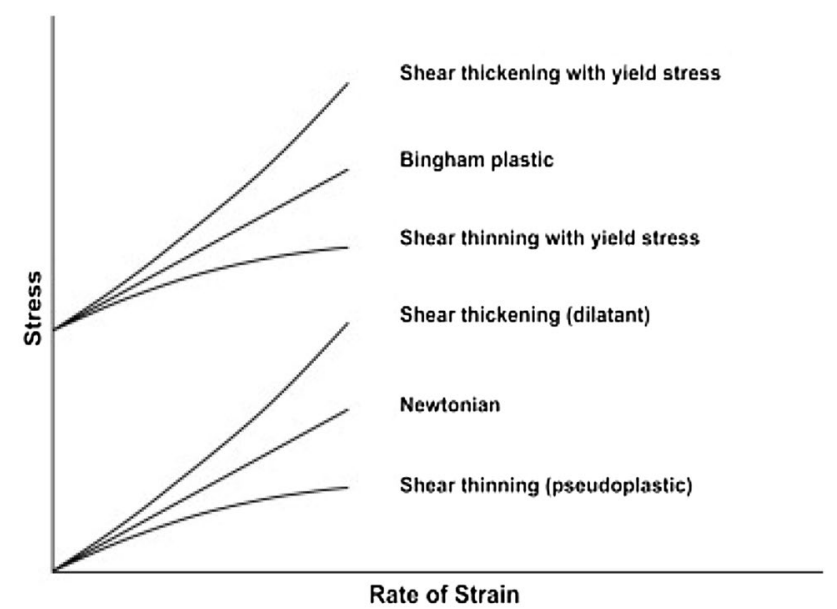

Fig. 2 The graph of stress versus strain in shear flow pectin's in okra concluded that okra shows high viscosity at low concentration and exhibited a shear-thinning behaviour. The flow behaviour of okra and Irvingia gabonensis was like other polysaccharides, exhibiting shear-thinning behaviour and increase in viscosity with concentration (Ndjouenkeu et al. 1995).

The viscosity of Cissus populnea also increased with increase in temperature between 20 and $60{ }^{\circ} \mathrm{C}$, however, at temperature above the boiling point $\left(70-150^{\circ} \mathrm{C}\right)$, the apparent viscosity decreased with increase in temperature. The apparent viscosity of Cissus populnea decreased as shear rate increased; this behaviour clearly shows shearthinning. Also increase in the rotor speed increases the molecular alignment in the flow direction, reducing flow resistance and viscosity, so Cissus populnea is said to exhibit pseudoplastic behaviour (Alakali et al. 2009). The work of Adeleye et al. (2015) confirmed the finding of Alakali et al. (2009) that viscosity of Cissus populnea increases at room temperature as the length of storage increases, the viscosity also changed with change in shear speed. At high shear speed, viscosity decreases because of the shear force of the spindle which reduces the internal friction leading to thinning. This indicate that Cissus populnea exhibit a pseudoplastic behaviour.

Gbonhinbor and Onyekonwu (2015) in their work on aqueous beans concluded that beans are natural polymer and exhibited polymeric behaviour which was observed by the steady rise and fall of the apparent viscosity at different shear rate. They also observed that the shearthinning behaviour and pseudoplastic nature of the fluid. Irvingia gabonensis has similar characteristics to xanthan gum (Ojukwu et al. 2013) by the show of shear-thinning behaviour, which confirm their pseudoplastic nature. The work of Ogolo et al. (2015) also affirms earlier research that natural polysaccharides like Brachystigia eurycoma and Irvingia gabonensis are polymer, exhibiting shearthinning behaviour. Ihebuzor and Onyenkonwu (2012), and Ade and Onyekonwu (2012) earlier work on natural polysaccharides have been confirmed that they are polymer, non-Newtonian and pseudoplastic fluid, exhibiting shear-thinning behaviour.

Hatscher (2016) reported that schizophyllan showed a high viscosifying efficiency and shear-thinning effect and retained its viscosity at high temperature of $135^{\circ} \mathrm{C}$ (Fig. 3). No loss of viscosity was found after about 300 days at $110^{\circ} \mathrm{C}$ under anaerobic condition. When the viscosity as a function of concentration was compared with commercially available EOR polymers, schizophyllan shows excellent viscosifying efficiency (Fig. 4). The mechanical stability also shows excellent resistance to shear compared especially to synthetic polymers (Fig. 5). The list of studies on natural polymer flow behaviour in porous media is shown in Table 2 .

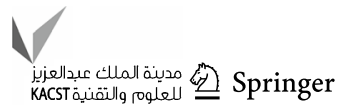


Fig. 3 Rheology of schizophyllan as natural polymer for EOR (Hatscher 2016)

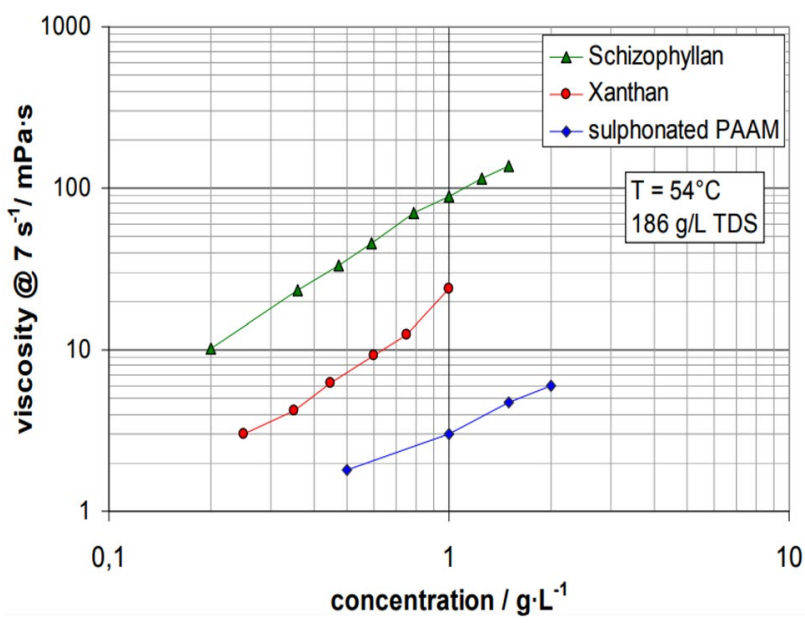

Fig. 4 Comparison of the viscosity of schizophyllan to commercial EOR Polymers (Hatscher 2016)

\section{Oil displacement using natural polymers}

When waterflooding is no more effective, as a result of early water production and low oil recovery at the breakthrough time, the next option is polymer flooding. Polymer flooding has been successful in terms of the economy and the technicality. When a polymer flooding is performed, the mobility ration between the displaced fluid and the displacing fluid become favourable compared to the normal

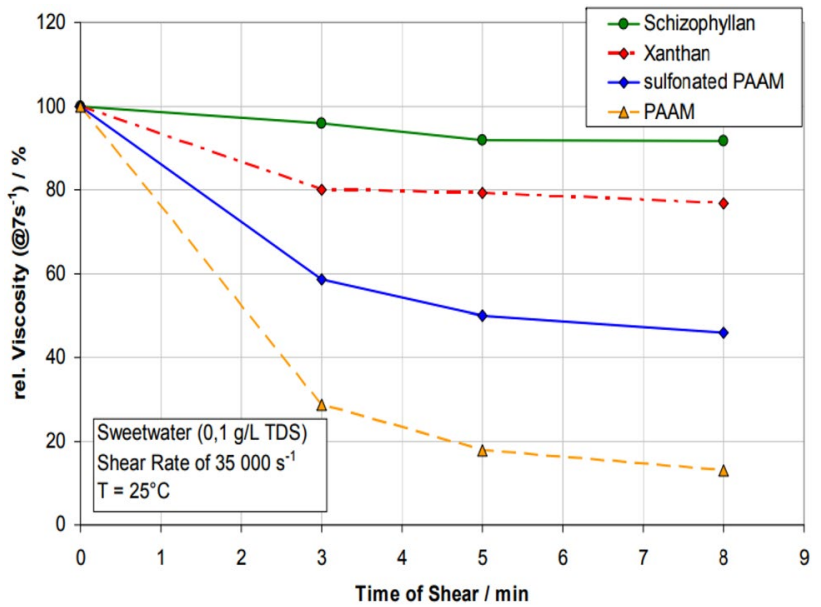

Fig. 5 Comparison of the mechanical stability of schizophyllan with commercial EOR polymers (Hatscher 2016)

water flooding, therefore, the sweep efficiency and the cumulative oil recovery is improved.

Oil displacement efficiency is the combination of the macroscopic efficiency and the microscopic efficiency. Macroscopic efficiency is the volumetric effect of the displacing fluid(s) in contacting oil zone, while microscopic displacement uses capillary forces to effectively mobile oil trapped at pore scale. Therefore, the purpose of oil displacement during polymer flooding is to improve the 
Table 2 List of studies on natural polymer flow behaviour in porous media

\begin{tabular}{|c|c|c|c|}
\hline Author/year & Polymer & Retention & Rheology \\
\hline Njouenkeu et al. (1995). & $\begin{array}{l}\text { Abelmonchus esculenta and } \\
\text { Irvingia gabonensis }\end{array}$ & NS & $\begin{array}{l}\text { 1. > Viscosity with Conc. } \\
\text { 2. Shear-thinning }\end{array}$ \\
\hline Huang et al. (2006). & Cassava starch & NS & $\begin{array}{l}\text { 1. }<\text { Apparent viscosity } \\
\text { with }>\text { shear rate } \\
\text { 2. Shear-thinning }\end{array}$ \\
\hline Che et al. (2008) & Dilute cassava starch & NS & $\begin{array}{l}\text { 1. Shear-thinning, } \\
\text { 2. Change from Newtonian to Non- } \\
\text { Newtonian @ > }>.4 \% \text { Conc. } \\
\text { 3. Power-law fluid } \\
\text { 4. Bingham model }\end{array}$ \\
\hline Sengkhamparn et al. (2009) & Okra & NS & $\begin{array}{l}\text { 1. High viscosity @ low Conc. } \\
\text { 2. Shear-thinning }\end{array}$ \\
\hline Alakali et al. (2009) & Cissus populnea & NS & $\begin{array}{l}\text { 1. }<\text { Apparent Visc. with temp } \\
\text { 2. }<\text { Apparent Visc. with rotor } \\
\text { speed } \\
\text { 3. < Apparent Visc. as shear rate > } \\
\text { 4. Shear-thinning }\end{array}$ \\
\hline Qiao and Zhu (2009) & Starch & $\begin{array}{l}\text { Injection of fluid to improve } \\
\text { injection profile abd prevent } \\
\text { fluid loss }\end{array}$ & NS \\
\hline Georgiadis et al. (2010) & Okra & NS & $\begin{array}{l}\text { 1. Exhibit Shear-thinning @ High } \\
\text { Conc. }\end{array}$ \\
\hline Alamri et al. (2012) & Okra & NS & $\begin{array}{l}\text { 1. > Shear stress @ High shear rate } \\
\text { 2. Pseudoplastic } \\
\text { 3. Power-law fluid }\end{array}$ \\
\hline Osuji and Onyenkonwu (2012) & Detarium microcarpum & $\begin{array}{l}\text { Absorbed water and solidify } \\
\text { blocking pores }\end{array}$ & NS \\
\hline Ade and Onyekonwu (2012) & $\begin{array}{l}\text { 1. Okra, } \\
\text { 2. Gum Arabic 3. Irvingia gabo- } \\
\text { nensis }\end{array}$ & NS & $\begin{array}{l}\text { 1. Pseudoplastic } \\
\text { 2. Shear-thinning }\end{array}$ \\
\hline Ihebuzor and Onyenkonwu (2012) & $\begin{array}{l}\text { 1. Arabic Gum 2. Irvingia gabo- } \\
\text { nensis }\end{array}$ & NS & $\begin{array}{l}\text { 1. Pseudoplastic } \\
\text { 2. Shear-thing } \\
\text { 3. Power-law fluid }\end{array}$ \\
\hline Ajabuego and Onyekonwu (2012) & $\begin{array}{l}\text { 1. Irvingia gabonensis 2. Brachy- } \\
\text { stiga eurycoma } \\
\text { 3. Exude gum }\end{array}$ & $\begin{array}{l}\text { 1. Pressure build-up with Irvingia } \\
\text { gabonensis } \\
\text { 2. Plugging }\end{array}$ & NS \\
\hline Liu et al. (2014) & Cassava Starch & NS & $\begin{array}{l}\text { 1. < Apparent viscosity with speed } \\
\text { of rotor } \\
\text { 2. Pseudoplastic } \\
\text { 3. Shear-thinning }\end{array}$ \\
\hline Ojukwu et al. (2013) & Irvingia gabonensis & $\begin{array}{l}\text { 1. }>\text { Viscosity led to }<\text { recovery } \\
\text { 2. Plugging }\end{array}$ & $\begin{array}{l}\text { 1. Shear thinning } \\
\text { 2. Pseudoplastic }\end{array}$ \\
\hline Ikeagwu and Adetila (2015) & 1. Starch 2. Irvingia gabonensis & $\begin{array}{l}\text { 1. > @ } 2.5 \mathrm{cp} \text { Visc. plugging } \\
\text { occur with Irvingia gabonensis }\end{array}$ & NS \\
\hline Adeleye et al. (2015) & Cissus populnea & NS & $\begin{array}{l}\text { 1. > Viscosity @ room Temp. with } \\
\text { storage } \\
\text { 2. < Viscosity @ high shear speed } \\
\text { 3. Shear-thinning } \\
\text { 4. Pseudoplastic }\end{array}$ \\
\hline $\begin{array}{l}\text { Gbonhinbor and Onyekonwu } \\
\text { (2015) }\end{array}$ & Beans & NS & $\begin{array}{l}\text { 1. Pseudoplastic } \\
\text { 2. Shear-thinning } \\
\text { 3. Natural polymer }\end{array}$ \\
\hline
\end{tabular}


Table 2 (continued)

\begin{tabular}{llll}
\hline Author/year & Polymer & Retention & Rheology \\
\hline Ogolo et al. (2015) & $\begin{array}{c}\text { 1. Brachystegia eurycoma 2. } \\
\text { Irvingia gabonensis }\end{array}$ & NS & $\begin{array}{l}\text { 1. Shear-thinning } \\
\text { 2. Natural polymers }\end{array}$ \\
Hatscher, (2016) & $\begin{array}{l}\text { Schizophyllan } \\
\text { Initial injection challenges before } \\
\text { the polymer injection overcome } \\
\text { with several stimulations and } \\
\text { improved water quality. }\end{array}$ \\
\hline
\end{tabular}

$N S$ not stated

macroscopic and microscopic displacement efficiency to improve oil recovery (Romero-Zeron 2012).

Therefore, the aim of polymer flooding is to control the mobility of the displacing fluid (water). Mobility, therefore, can be simply defined as the ratio of the relative permeability of oil or water to the viscosity of the same fluid, be it water or oil (Kotlar et al. 2007). The polymer thickens the water and reduces mobility and prevents viscous fingering; polymer also reduces the relative permeability within the porous media. Mobility ration is classed 'favourable' when $M \leq 1$ and 'unfavourable' when $M \geq 1$. But Sheng (2011), defined mobility ratio as the ratio of the displacing fluid mobility to that of oil, multiplied by the normalised moveable oil saturation $\left(S_{\mathrm{o}}\right)$.

Reducing the relative permeability of water $\left(K_{\mathrm{rw}}\right)$ while proposing relative permeability reduction of oil $\left(K_{\mathrm{ro}}\right)$ can also reduce mobility of polymer (Niu et al. 2006). Formation of layer on the pore walls by the adsorbed polymer; flow pathway segregation of oil and water; wettability alteration and swelling/shrinkage of the polymer depending on the phase flow. These activities can lead to unequal permeability reduction.

The most important issue in polymer flooding is how to improve oil recovery effectively and how the flooding process is assessed. Polymer alone cannot alter the residual oil saturations, but both water flooding and polymer flooding will produce the moveable oil with time. Polymer flood is designed to bring forward the production profile that is the polymer flood should not exceed the reservoir development plan, irrespective of the mechanism used.

The economic limit, which is the maximum water-cut that can be handled, shows that polymer can indeed obtain additional oil which we refer to as 'incremental oil'. So, incremental oil is the measured difference between the water flood and the polymer flood. Incremental oil is usually high at the intermediate stage than at the final value calculated; this is because the same oil produced earlier in the polymer flood as well as in the water flood will still be produced later during the economic waterflood. Therefore, one of the achievements of polymer flooding is oil brought forward in time. Which some might be recovered at the project timelife, while others later as in the case above. Both oil will assist in the petroleum economics when the cash discounted flow is calculated. Therefore, incremental oil is important because it helps in the payback of the initial investment and makes the payback period short (Sorbie 1991)

Osuji and Onyenkonwu (2012) work was on Detarium microcarpum natural polymer, even though Detarium microcarpum exhibited shear-thinning behaviour and the oil recovery was about $39.58 \%$, Detarium microcarpum still absorbed water and solidified blocking the pore spaces. Meanwhile, in the work of Ihebuzor and Onyenkonwu (2012) on okra, gum Arabic and Irvingia gabonensis. Gum Arabic was more viscous than okra and Irvingia gabonensis, but okra had the highest recovery at $63.16 \%$, while gum Arabic and Irvingia gabonensis was 53.01 and $47.37 \%$, respectively. Irvingia gabonensis had a higher mobility than cassava starch, but the recovery rate of cassava starch was higher (Samuel and Onyekonwu 2012). The work of Ade and Onyekonwu (2012) on gum Arabic, okra, and Irvingia gabonensis is in line with that of Ihebuzor and Onyenkonwu (2012). They reported that gum Arabic yielded the highest viscosity at equal concentration, but okra gave the highest recovery at $63.7 \%$; gum Arabic 53.1\% and Irvingia gabonensis $47.3 \%$. Ajabuego and Onyekonwu (2012) work was on Irvingia gabonensis, exudate gum and Brachystegia eurycoma. Their report also confirmed the earlier work on Irvingia gabonensis that there was pressure build-up and low flow rate was observed; this is due to formation plugging but exudate gum gave the highest recovery with $35.48 \%$; Irvingia gabonensis $31.17 \%$ and Brachystegia eurycoma was $26.67 \%$.

Ojukwu et al. (2013) in their work on Irvingia gabonensis as a biopolymer reported that Irvingia gabonensis has the same characteristics as xanthan that is already in use with a $22.7 \%$ recovery of original oil in place and incremental recovery of $17.9 \%$ after water flooding. The work of Ojo et al. (2013) confirmed earlier report that okra has a high recovery rate when used in flooding experiment. Ikeagwu and Adetila (2015) also reported that oil recovery was higher with starch than Irvingia gabonensis.

Gbonhinbor and Onyekonwu (2015) experimented with aqueous beans protein to recovery oil and reported a $44 \%$ recovery rate; they also recommended it to be used for recovery of heavy oil. Ogolo et al. (2015), in their work on 'The

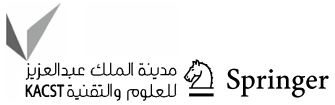


Performance of Local and Foreign Agents for Enhance Oil Recovery', concluded that the addition of polymer to other agents gave the highest recovery.

Goa (2016) experimented with schizophyllan solution to recover oil and reported a high recovery rate. Field trial in Bockstedt Germany shows good and continuous injectivity. This led to a positive trend of incremental oil in the observation well, further testing of schizophyllan in single well test mode confirmed the performance of schizophyllan in the reservoir (Hatscher 2016). The list of studies on oil recovery in natural polymer flooding is presented in Table 3.

\section{Environmental applications issues associated with natural polymers}

The environmental application problems associated with natural polymers are few compared to the synthetic polymers, and they can be classified into two major groups: environmental issues associated with manufacturers of natural polymers and environmental issue associated with the end users, in this case the oil and gas industry.

\section{Environmental issues associated with manufacture of natural polymers}

Globally, industrial waste represents the main source of environmental pollution. Agro-industrial effluent and starch industry pose a serious threat to the environment and are among the major source of environmental pollution. It affects the quality of drinking water, soil microflora and aquatic ecosystem.

Processing of natural polymers especially starch has gone beyond the traditional methods and requires enough water and yet often sited in areas of water scarcity. Starch produces high effluent high in organic content, if not treated may result in stagnant pond where foul odour emanates. Some like most cereal products generate visible dust that pollutes the air, with view of the factors highlighted above, environmental issues associated with manufacture of natural polymers can be grouped into; (a) waste water, (b) solid waste, (c) chemical use, and (d) atmospheric pollution (Niu et al. 2006).

Table 3 List of studies on oil recovery in natural polymer flooding

\begin{tabular}{|c|c|c|c|}
\hline Author/year & Polymer & $\begin{array}{l}\text { Maximum } \\
\text { recovery } \\
(\%)\end{array}$ & Remarks \\
\hline Osuji and Onyenkonwu (2012) & Detarium microcarpum & 39.58 & $\begin{array}{l}\text { Detarium microcarpum absorbs water and solidifies, blocking } \\
\text { pore spaces }\end{array}$ \\
\hline Ihebuzor and Onyenkonwu (2012) & $\begin{array}{l}\text { 1. Okra } \\
\text { 2. Gum Arabic } \\
\text { 3. Irvingia gabonensis }\end{array}$ & $\begin{array}{l}63.16 \\
53.01 \\
47.37\end{array}$ & $\begin{array}{l}\text { Gum Arabic is more viscous, but okra recovered more oil than } \\
\text { Gum Arabic and Irvingia gabonensis }\end{array}$ \\
\hline Samuel and Onyekonwu (2012) & $\begin{array}{l}\text { 1. Cassava Starch } \\
\text { 2. Irvingia gabonensis }\end{array}$ & NS & Oil recovery was higher with cassava than Irvingia gabonensis \\
\hline Ade and Onyekonwu (2012) & $\begin{array}{l}\text { 1. Okra } \\
\text { 2. Irvingia gabonensis } \\
\text { 3. Gum Arabic }\end{array}$ & $\begin{array}{l}63.7 \\
47.3 \\
53.01\end{array}$ & $\begin{array}{l}\text { Gum Arabic solution yielded the highest viscosity with equal } \\
\text { concentration, but okra gave the highest recovery }\end{array}$ \\
\hline Ajabuego and Onyekonwu (2012) & $\begin{array}{l}\text { 1. Irvingia gabonensis } \\
\text { 2. Brachystegia eurycoma } \\
\text { 3. Exudate gum }\end{array}$ & $\begin{array}{l}31.17 \\
26.67 \\
35.48\end{array}$ & $\begin{array}{l}\text { Exudate Gum gave the highest recovery, during Irvingia gabo- } \\
\text { nensis polymer flooding, a there was pressure build-up and } \\
\text { low flow rate as a result of plugging }\end{array}$ \\
\hline Ojo et al. (2013) & Okra & NS & Showed high recovery rate, confirmed earlier studies \\
\hline Ojukwu et al. (2013) & Irvingia gabonensis & 22.7 & Similar characteristics to Xanthan that is already in use \\
\hline Ikeagwu and Adetila (2015) & $\begin{array}{l}\text { 1. Cassava starch } \\
\text { 2. Irvingia gabonensis }\end{array}$ & NS & $\begin{array}{l}\text { Cassava starch recorded higher recovery than Irvingia gabon- } \\
\text { ensis }\end{array}$ \\
\hline Gbonhinbor and Onyekonwu (2015) & 1. Aqueous beans & 44.6 & $\begin{array}{l}\text { Exhibits polymeric behaviour and will be effective for recover- } \\
\text { ing heavy oil }\end{array}$ \\
\hline Ogolo et al. (2015) & $\begin{array}{l}\text { 1. Irvingia gabonensis } \\
\text { 2. Brachystegia eurycoma }\end{array}$ & NS & Improved oil recovery, confirm earlier work \\
\hline Goa (2016) & Schizophyllan & 55 & $\begin{array}{l}\text { Core flooding revealed good resistance factor and field pilot } \\
\text { confirmed good injectivity and early result in oil production }\end{array}$ \\
\hline Hatscher (2016) & Schizophyllan & NS & Positive trend of incremental oil in the observation well \\
\hline
\end{tabular}

$N S$ not stated 
(a) Waste water The water released from squeezing starch, though relatively small is the main problem because of its biological oxygen demand and cyanide concentration. The water produced from starch derivatives are directed into pits for conversion; this may lead to leaching and contaminate groundwater, while over flow may affect surface water. In most cases, it is returned into land or shallow streams. The environmental impact may be as a result of addition of substances, heat or micro-organism to the water, the addition of microorganism can affect the quality of the water, alter the aquatic ecology, which will in turn affect plants, animal and human health.

(b) Solid waste Solid waste might be in the form of peels, pulp waste, shells in the case of Irvingia gabonensis. Detarium microcarpum and Brachystegia eurycoma. Inappropriate storage for a long period can lead to foul smell and during the raining season; it can accumulate to form leachate to contaminate ground water.

(c) Chemical use Most cassava starch factory uses, sulphur dioxide as anti-microbial and bleaching agent. The sulphur is released into groundwater as waste; the rest is released into the atmosphere. Report has it that it is a safe practice but no evidence to back up this claim.

(d) Atmospheric pollution Most of the cyanide released during processing of starch end up in waste water and are evaporated into the atmosphere; however, hydrogen cyanide $(\mathrm{HCN})$ is released during processing and is harmful to heath. Dust from shafts in the case of aqueous beans is also a problem, and the odour from beans, fermentation of organic matter in cassava waste.

\section{Environmental issues associated with end users}

The environmental issues with polymer flooding in the oil and gas industry affect both ground water, the environment and aquatic ecosystem, depending on the type of waste and site of discharge (Olajire 2014).

Most discharge are avoidable, while other are unavoidable: the unavoidable discharge includes discharge due to accident from during transportation of polymers from shore to onshore; discharge of disqualified fresh solutions, while the avoidable discharge includes recovery of polymer from produced water, but large sludge will need disposal; failure of re-injection facilities; leaking storage tanks; leaking pipes and casing. Therefore, if these proposed natural polymers are not managed properly, there will affect our environment, health, through the following ways;

(a) Surface water deterioration and ground water contamination The problem encountered here is usually seepage of pollutants from disposal pits and accidental spills of polymers, escape of brines containing poly- mers from depleted reservoir or disposal formation, migration by natural flow out of the reservoir into fresh water aquifer and to surface water. This polymer may be toxic to organism and carcinogenic if its transported in large quantity to ground or surface water (Olajire 2014). For all these to take place, there must be a communication between the pollutant source and the ground water, this might be through corroded cases, underground drainage channels, faults and fractures. Another major problem in polymer flooding is the amounts of polymer left in the formation after the end of the operation, which will increase their chances of migration to fresh water source.

(b) Interaction of polymer contaminants with porous media: The flow of contaminants in porous media is affected by the flow fields, chemical and biochemical reaction which alter the chemistry. Mechanism such as microbial synthesis, solution and precipitation, adsorption, radioactive decay, reduction and oxidation, acid base reaction, desorption and ions pairing plays a major role. Basically, physical and biochemical mechanism affects the flow of contaminants in porous media; the physical mechanism includes mechanical entrapments, molecular diffusion, advection and hydrodynamic dispersion. Advection is attributed to the contaminant movement in flowing water, mechanical entrapment is the plugging of the pores by molecules with large diameter than that of the channel, dispersion allow the contaminants to travel through pores that offer less resistance, while molecular diffusion allow natural mass transfer between adjacent layers of fluids in laminar due to concentration gradient (Meister et al. 1980). Biochemical mechanism is less frequent, mostly by oxidation-reduction reaction, which is a chemical process often initiated by biological activities, where the oxidised particle is less mobile than the reduced one.

\section{Proffered solutions to challenges}

Processor unit should be built to threat waste water before it is released to the environment. Ponding method is cheap and easy, where a cluster of ponds is constructed, the first pond is usually anaerobic to deal with the problem of foul smell. Also, anaerobic reactor is recommended.

Solid waste can be processed to animal feeds, and some can be used as landfills if necessary precautions are in place.

Environmental monitoring system and law should be in place, and records kept monitoring changes in ecological habitat in around processing sites.

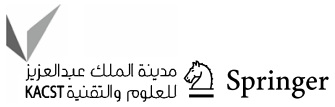


In the case of spills and seepage, prevention control and counter measures should be in place for early detection and control.

Monitoring programmes should be in place for all EOR project sites with fresh water aquifers.

\section{Future directions for natural polymers}

Nanotechnology has found its way to petroleum engineering, and it is a well-accepted path in oil and gas industry to recover trapped oil in the reservoir (Onyekonwu and Ogolo 2010; Ogolo et al. 2012; Bayat and Junin 2015; Mahmoud et al. 2016; Nwidee et al. 2017; Yue et al. 2018); therefore, there is need to synthesise these natural polymers to nanoparticle (Chin et al. 2011; Azeez and Onukwuli 2016) for improved performance that can perform better than polymers already in use (Yue et al. 2018).

The nanoparticles can also be used to solve problem of fines migration in the oil industry (Ogolo et al. 2017; Yue et al. 2018) and as drilling fluids additives to improve the rheological properties (Smith et al. 2018; Afolabi et al. 2018).

\section{Conclusions}

1. The main aim of this paper is to bring to light polymers available in nature and their flow behaviour in porous media for enhanced oil recovery application.

2. Natural polymer flow was described based on their retention and rheology in porous media.

3. There are three major mechanisms which act on polymer when it flows through porous media; polymer adsorption, mechanical entrapment, and hydrodynamic retention.

4. Experimental results show that natural polymers can recover additional oil from the reservoir.

5. Be that as it may, they are some environmental issues associated with its production such as solid waste, waste water, pollution and in application, it can contaminate ground water aquifer.

6. The flow of contaminants in porous media is affected by the flow fields, chemical and biochemical reaction which alter the chemistry. The physical mechanism includes mechanical entrapments, molecular diffusion, advection and hydrodynamic dispersion, while the biochemical involves oxidation and reduction.

7. Most of these natural polymers are consumable food; therefore, it can lead to food shortage.
Acknowledgements The authors would like to thank the Ministry of Higher Education (MOHE), Malaysia, and Universiti Teknologi Malaysia (UTM), for supporting this research through Research Management Grant Vot. No. Q. J30000.2546.14H50

Open Access This article is distributed under the terms of the Creative Commons Attribution 4.0 International License (http://creativeco mmons.org/licenses/by/4.0/), which permits unrestricted use, distribution, and reproduction in any medium, provided you give appropriate credit to the original author(s) and the source, provide a link to the Creative Commons license, and indicate if changes were made.

\section{References}

Abbas AH, Sulaiman WR, Jafaar MZ, Agi AA (2017) Micelle Formation of Aerosol-OT in Sea Water Salinity. Arab J Sci Eng 1-5. https://doi.org/10.1007/s13369-017-2593-0

Abuajah CI, Alonge AF (2013) Physical Properties of African Kidney Bean (Phaseolus vulgaris) Relevant to its Processing. Food Biol 2(2):18-23

Ade E, Onyekonwu MO (2012) Experimental Study of Enhancing Oil Recovery Using Local Polymers. M. Eng. Thesis, Department of Petroleum and Gas, University of Port Harcourt-Nigeria

Adedeji AA, Alakali J, Adewale PO, Ngadi MO (2012) Thermophysical properties of detarium microcarpum seed flour. LWT-Food Sci Technol 47(2):233-237

Adeleye AO, Oyewo MN, Odeniyi MA (2015) Physiochemical and rheological property characterisation of cissus populnea gum extracted by different solvent. West Afr J Pharm 26(1):113-126

Afolabi RO, Orodu OD, Seteyeobot I (2018) predictive impact of silica nanoparticles on fluid loss of water base drilling mud. Appl Clay Sci 151:37-45

Agi AA, Junin R, Gbonhinbor JR, Onyekonwu MO (2017) exploitation of thin oil rims with large associated gas cap. Int J Pet Eng 3(1):14-48

Ahmed T, McKinney P (2005) Advanced reservoir engineering. Gulf Professional Publishing, Houston, pp 291-299

Ajabuego I, Onyekonwu M (2012) Enhanced Oil Recovery Using Local Polymer. (M.Eng Thesis), Department of Petroleum and Gas, University of Port Harcourt, Nigeria

Akpata MI, Miachi OE (2001) Proximate composition and selected functional properties of detarium microcarpum. Plant Food Human Nutr 56(4):297-302

Alakali SJ, Irtwange VS, Mkavga M (2009) Rheological characteristics of food gum (Cissus populnea). Afr J Food Sci 3(9):237-242

Alamri S, Mohamed A, Hussein S, Xu J (2012) Effect of okra extract on properties of wheat, corn, and rice starches. J Food Agric Environ 10(1):217-222

Araujo-Farro PC, Sobral JP, Menegalli FC (2005) Comparison of starch pasting and retrogradation properties of Quinoa (Chenopodium quinoa willd), rice, potatoes, cassava, wheat and corn starches. In: 2nd Mercosur congress on chemical engineering, 4th mercosur congress on process system engineering, Sao Paulo, Brazil

Aviara NA, Onaji ME, Lawal AA (2015) Moisture Dependent Physical Properties of Detarium microcarpum Seed. Agric Eng Int CIGR J 17(4):311-326

Azeez TO, Onukwuli DO (2016) Modified food gum (Cissus populnea) Fibres: microstructural behaviour, physio-mechanical properties and kinetics of water absorption. J Eng Appl Sci 11:17 
Bamidele OP, Ojedokun OS, Fasogbon BM (2015) Physio-Chemical Properties of Instant Ogbono (Irvingia gabonesis) Mix Powder. Food Sci Nutr 3(4):313-318

Bashir M, Haripriya S (2016) Assessment of Physical and Structural Characteristics of Almond Gum. Int J Biol Macromol 93:476-482

Bayat AE, Junin R (2015) Transportation of metal oxide nanoparticles through various porous media for enhanced oil recovery. In: Paper SPE-176365-MS, presented at the SPE/IATMI Asia Pacific Oil and Gas conference and exhibition, held in Nusa Dua, Bali, Indonesia, 20-22 October

Belibi PC, Daou TJ, Ndjaka JM, Nsom B, Michelin L, Durand B (2014) A comparative study of some properties of cassava and tree cassava starch films. Phys Proc 55:220-226

Chauveteau G, Kohler N (1974) Polymer flooding: the essential element for laboratory evaluation. SPE 4745. In: Proceedings of the improved oil recovery symposium of SPE-AIME, Tulsa, OK, 22-24 April

Che L, Li D, Wang L, Ozkan N, Chen X, Mao Z (2008) Rheological properties of dilute aqueous solutions of cassava starch. Carbohydr Polym 74:385-389

Chen G, D'Auria M (2010) Identification of the properties of gum arabic used as a binder in 7.62-mm ammunition primer, technical report, ARMET-TR-09069. Munition Engineering Technology Centre, New Jersey

Chin FS, Pang CS, Tay HS (2011) Size controlled synthesis of starch nanoparticles by a simple nanoprecipitation method. Carbohydr Polym 86:1817-1819

Daoub MA, Elmubarak AH, Misran M, Hassan AE, Osman ME (2016) Characterisation and Functional Properties of some Natural Acacia Gums. J Saudi Soc Agric Sci. https://doi.org/10.1016/j.jssas .2016 .05 .002

Desremaux L, Chauveteau G, Martin M (1971) Communication NO. 28 ARTEP Colloquium, Paris

Dominguez JG, Willhite GP (1977) Retention and flow characteristics of polymer solution in porous media. Soc Pet Eng J 17:111-121

Farouq-Ali SM, Thomas S (1996) The promise and the problems of enhanced oil recovery methods. J Can Pet Technol 35(7):57-63

Gbadamosi SO, Oladeji BS (2013) Comparative studies of the functional and physio-chemical properties of isolated cassava, cocoyam and breadfruit starches. Int Food Res J 20(5):2273-2277

Gbonhinbor JR, Onyekonwu MO (2015) Experimental and simulation study on aqueous protein to improve oil recovery. Int J Pet Eng 1:4. https://doi.org/10.1504/IJPE.073536

Georgiadis N, Ritzoulis C, Sioura G, Kornezou P, Vasiliadou C, Tsioptsias C (2010) Contribution of okra extract to the stability and rheology of oil-in-water emulsions. Food Hydrocoll 25:991-999

Goa C (2016) Application of a novel biopolymer to enhance oil recovery. J Pet Explor Prod Technol 6:749-753

Hatscher S (2016) Schizophyllan as a biopolymer for EOR lab and field results. Winterfall, International Energy Agency (IEA), Germany

Herzig JP, Leclerc DM, LeGoff P (1990) Flow of suspension through porous media- application to deep bed filtration. Ind Eng Chem 62:8

Huang Z, Lu J, Li X, Tong Z (2006) Effect of mechanical activation on physio-chemical properties and structure of cassava starch. Carbohydr Polym 68:128-135

Ihebuzor N, Onyenkonwu MO (2012) An experimental research on enhanced oil recovery using local polymers. M. Eng Thesis, University of Port Harcourt -Nigeria

Ikeagwu C, Adetila S (2015) The Study of Local Polymers on Enhanced Oil Recovery. Archives of Applied Science and Research 7:48-55

Ikeagwu C, Nyah FJ, Onyekonwu MO, Ogolo NA, Ubani C (2013) Study of alcohol mixtures for enhanced oil recovery. In: paper SPE - 167547 presented at the Nigerian annual conference and exhibition held in Lagos, Nigeria, 30th July-1 August
Ikegwu OJ, Okechukwu PE, Ekumankana EO (2010) Physio-Chemical and pasting properties of flour and starch from achi brachystegia eurycoma Seed. J Food Technol 8(2):58-66

Joshi SJ, Al-Wahaibi YM, Al-Bahry S, Al-Bemani AS, Al-Hashmi A, Samuel P, Sassi M, Al-Farsi H, Al-Mandhari MS (2016) Production and application of schizophyllan in microbial enhance oil recovery. In: Paper SPE-179775-MS, presented at the SPE EOR conference at oil and gas West Asia, Muscat, Oman, 21-23 March

Karathanos VT, Saravacos GD (1993) Porosity and Pore Size Distribution of Starch Materials. J Food Eng 18(3):259-280

Kotlar HK, Selle O, Torsaeter O (2007) Enhanced oil recovery by comb flow:polymer floods revitalised. In: SPE 106421 presented at the international symposium on oilfield chemistry, Houston, 28 Feb.-2 March

Larson RG (1992) Flow-induced mixing, demixing and phase transition in polymeric fluids. Rheol Acta 31:497-520

Lazar I, Petrisor I, Yen T (2007) Microbial enhanced oil recovery (MEOR). Pet Sci Technol 25(11):1353-1366

Liu J, Guo L, Yang L, Liu Z, He C (2014) Study on the rheological properties of cassava starch adhesives. Adv J Food Sci Technol 6(3):374-377

Maerker JM (1973) Dependence of polymer retention on flow rate. J Pet Tech 25:1307

Mahfoudhi N, Chouaibi M, Donsi F, Ferrari G, Hamdi S (2012) Chemical composition and functional properties of gum exudates from the trunk of almond tree (Prunus dulcis). Food Sci Technol Int 18(3):241-250

Mahmoud O, Nasr -El-Din HA, Vryzas Z, Kelessidis VC (2016) Nanoparticle-based drilling fluids for minimizing formation damage in hp/ht applications. In: Paper SPE-178949-MS presented at spe international conference and exhibition on formation damage control, Lafayette, Louisiana, USA, 24-26 February

Marquezi M, Gervin VM, Watanabe LB, Moresco R, Amante ER (2017) Chemical and functional properties of different common brazilian bean (Phaseolus vulgaris) cultivars. Braz J Food Technol 20:1-9

Meister J, Pledger H, Hogen-Esch T, Butler G (1980) Retention of polyacrylamide by Berea sandstone, baker dolomite, and na kaolinite during polymer flooding. In: SPE-8981 SPE fifth international symposium on oil field and geothermal chemistry, Stanford, 61

Ndjouenkeu R, Goycoolea FM, Morris ER, Akingbala JO (1995) Rheology of okra(Hibiscus esculenta) and dika nut (Irvingia gabonesis) polysaccharides. Carbohydr Polym 29:263-269

Ndukwu MC (2009) Determination of selected physical properties of brachystegia eurycoma seeds. Res Agric Eng 55(4):165-169

Niu JG, Chen P, Shao ZB, Wang DM, Sun G, Li Y (2006) Research and development of polymer enhanced oil recovery. In: Cao HQ (ed) Research and development of enhance oil recovery in Daqing. Petroleum Industry Press, Beijing, pp 227-325

Nwidee LN, Al-Anssari S, Barifcani A, Sarmadivaleh M, Lebedev M, Iglauer S (2017) Nanoparticles wetting behaviour of fractured limestone formation. J Pet Sci Eng 149:782-788

Nwigbo SC, Ngini JO, Atuanya CU (2013) Physical and Mechanical Property of Irvingia gabonesis and Irvingia wombolu at Varying Moisture Content and Temperature. Int J Mult Discip Sci Eng 4(6): $10-14$

Ogaji IJ, Nan A, Hoag SW (2012) A novel extraction method and some physiochemical properties of extractives of irvingia gabonesis seeds. J Young Pharm 4(2):66-72

Ogolo NA, Olafuyi O, Onyekonwu MO (2012) Enhanced oil recovery using nanoparticles. In: Saudi Arabia section technical symposium and exhibition, $\mathrm{p} 9$

Ogolo NA, Ogiriki S, Onyiri V, Nwosu T, Onyenkonwu MO (2015) Performance of foreign and local agents for enhanced oil recovery

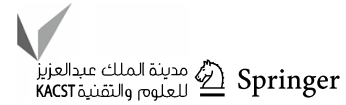


of Nigerian Crude. In: SPE annual conference and exhibition held in Lagos, Nigeria, 4-6 August. SPE Paper-178305-MS

Ogolo NA, Iloke E, Godstime TG, Onyekonwu MO (2017) Mobilization of clayey fines by different water salinity values in the presence of aluminium oxide nanoparticles. In: Paper SPE189125-MS, presented at the SPE international annual conference and exhibition, Lagos, Nigeria, 31 July-2 August

Ojo VO, Onyekonwu MO, Ogolo NA, Ubani C (2013) Effect of viscosity of alkaline/surfactant/polymer on enhanced oil recovery in heterogenous sands. In: SPE annual conference and exhibition held in Lagos, Nigeria, 30 July- 1 August. SPE-167550

Ojukwu C, Oyekonwu M, Ogolo O, Ubani C (2013) Alkaline surfactant polymer (local) enhanced oil recovery: an experimental approach. In: SPE-paper 167529 presented at SPE annual conference and exhibition held in Lagos, Nigeria.,30 July- 1 August

Okolo BI, Nnaji PC, Menkiti MC, Ugonabo VI, Onukwuli OD (2014) Application of single angle turbidimetry on coag-flocculation effect of detarium microcarpum seed in brewery effluent. Mat Sci Appl 5:416-429

Olajire AA (2014) Review of EOR ASP (Alkaline surfactant polymer enhanced oil recovery). Technol Pet Ind Prospect Chall Energy 77:963-982

Onimawo IA, Oteno F, Orokpo G, Akubor PI (2003) Physiochemical and nutrient evaluation of African bush mango (Irvingia gabonesis) seeds and pulps. Plant Foods Hum Nutr 58(3):1-6

Onweluzo JC, Vijayalakshmi MR, Vijayanand P, Eipeson WE (1999) Detarium microcarpum polysaccharide as a stabilizer in processed fruit products. LWT-Food Sci Technol 32(8):521-526

Onyekonwu MO, Ogolo NA, (2010) Investigating the use of nanoparticles in enhancing oil recovery. In: 34th annual SPE international conference and exhibition held in Tinapa, SPE-140744, p 14

Osuji C, Onyenkonwu M (2012) Using alkaline-surfactant-polymer to improve oil recovery. (M. Eng. Thesis) Department of Petroleum and Gas University of Port Harcourt

Owolarafe OK, Shotonde HO (2004) Some physical properties of fresh okra fruit. J Food Eng 63(3):299-302

Owuamanam CI, Obeleagu SO, Ogueke CC, Iwouno JO, Nwakaudu AA, Nwachukwu I (2016) Functional properties of seed flours of Detarium microcarpum and Mucuna Sloanei as affected by sodium chloride and palm oil: a response surface methodology approach. Futo J Ser 2(2):361-378

Qiao R, Zhu W (2009) Evaluation of Modified Cationic Starch for Impeding Polymer Channeling and in-depth Profile Control after Polymer Flooding. J Ind Eng Chem 16:278-282

Romero-Zeron L (2012) Advances in enhanced oil recovery. In: Romero-Zeron L (ed). Introduction to enhanced oil recovery (EOR) process and bioremediation of oil contaminants sites. In Tech, Rijeka. ISBN 978-953-51-0629-6
Samuel S, Onyekonwu MO (2012) Enhanced oil recovery using local polymers. M. Eng. Thesis, Department of Petroleum and Gas, University of Port Hracourt, Nigeria

Sengkhamparn N, Sagis L, Vries R, Scols H (2009) Physiochemical properties of pectins from okra (Abelmonchus Esculenta). Food Hydrocoll 24:35-41

Sheng JJ (2011) Modern chemical enhanced oil recovery. Gulf Professional Publishers, Houston, pp 101-202

Smith SR, Rafati R, Haddad AS, Cooper A, Hamidi Hossein (2018) Application of aluminium oxide nanoparticles to enhance rheological and filtration properties of water Based muds at HPHT conditions. Coll Surf Physiochem Eng Asp 537:361-371

Sochi T (2010) Non-Newtonian flow in porous media. Polymer 51(22):5007-5023

Sorbie K (1991) Polymer improved oil recovery blackie. Glasgow Lond 1991:1-5

Stosur GJ (2003) EOR: past, present and what the next 25 years may bring. Soc Pet Eng Inc SPE 84864:2-5

Szabo MT (1975) Some aspect of polymer retention in porous media using ${ }^{14} \mathrm{C}$-tagged Hydrolysed Polyacrylamide. Soc Pet Eng J 15:323

Uhumwangho MU, Ileje IL (2014) Preliminary evaluation of the suspending properties of brachystegia eurycoma gum on metronidazole suspension. Int Curr Pharm J 3(11):328-330

Wani IA, Sogi DS, Wani AA, Gill BS (2013) Physio-chemical and functional properties of flours from Indian kidney bean (Phaseolus vulgaris L) Cultivars. LWT-Food Sci Technol 53(1):278-284

Wei Y, Sepehrnoori K (2014) An efficient reservoir-simulation approach to design and optimize unconventional gas production. J Can Pet Technol 53(2):109-121

Willhite GP, Dominguez JG (1977) Mechanism of Polymer Retention in Porous Media. In: Shah DO, Schechter RS (eds) Improved oil recovery by surfactant and polymer flooding. Academic Press, Cambridge, pp 511-554

Yue M, Zhu W, Han H, Song H, Long Y, Lou Y (2018) Experimental research on the remaining oil distribution and recovery performances after nano-micron polymer particles injection by direct visualization. Fuel 212:506-514

Zaharuddin ND, Noordin MI, Kadivar A (2014) The use of Hibiscus esculenta (Okra) Gum in sustaining the release of propranolol hydrochloride in a solid oral dosage. Biomed Res Int. https://doi. org/10.1155/2014/735891

Publisher's Note Springer Nature remains neutral with regard to jurisdictional claims in published maps and institutional affiliations. 